\title{
Wound-Healing potential of Sebastiania hispida (Mart.) Pax (Euphorbiaceae) ointment compared to low power laser in rats
}

\author{
E. S. Rizzi ${ }^{a}$, D. M. Dourado ${ }^{b}$, R. Matias $^{a}$, J. A. I. Muller ${ }^{b}$, J. F. Guilhermino, \\ A. T. G. Guerrero ${ }^{\text {, D. D. Loreira }}$, B. A. K. Silva and M. Barbosa-Ferreira ${ }^{f}$ \\ aPrograma de Pós-graduação em Meio Ambiente e Desenvolvimento Regional, Universidade Anhanguera - UNIDERP, \\ Rua Alexandre Herculano, 1400, CEP 79037-280, Campo Grande, MS, Brazil \\ bPrograma de Pós-graduação em Doenças Infecciosas e Parasitárias, Universidade Federal de Mato Grosso do Sul - \\ UFMS, Avenida Costa e Silva, s/n, Campus Universitário, CEP 79070-900, Campo Grande, MS, Brazil \\ 'Meio Ambiente e Saúde: Biodiversidade e Agronegócio, Fundação Oswaldo Cruz - FIOCRUZ, Rua Gabriel Abrão, \\ 92, Jardim das Nações, CEP 79081-470, Campo Grande, MS, Brazil \\ dDepartamento de Produtos Naturais, Instituto de Tecnologia Farmacêutica, Fundação Oswaldo Cruz - FIOCRUZ, \\ Rua Sizenando Nabuco, 100, CEP 21041-250, Rio de Janeiro, RJ, Brazil \\ eUniversidade Federal do Piauí - UFPI, Campus Ministro Reis Velloso, Avenida São Sebastião, 2819, Reis Velloso, \\ CEP 64202-020, Parnaíba, PI, Brazil \\ fPrograma de Pós-graduação em Agro Produção e Gestão Industrial, Universidade Anhanguera - UNIDERP, \\ Rua Alexandre Herculano, 1400, CEP 79037-280, Campo Grande, MS, Brazil \\ *e-mail: douradod@uol.com.br
}

Received: October 4, 2015 - Accepted: April 22, 2016 - Distributed: August 31, 2017

(With 5 figures)

\begin{abstract}
Impaired wound healing represents a serious complication in some pathologies and the use of plant extracts has proved to improve tissue repair. The objectives of this study were to evaluate the healing potential of the ointment of Sebastiana hispida compared with Aluminum-Gallium Indium-Phosphide Laser (InGaAlP) in surgically induced wounds in rats and to perform the phytochemical analysis. The phytochemical analysis was performed in the classic way and also by HPLC. A controlled study was developed with 80 rats $(200-250 \mathrm{~g})$ in which a linear excision was performed in the dorsal region after shaving, measuring $2 \mathrm{~cm} \times 1 \mathrm{~cm}$ (epidermis and dermis) exposing the muscle fascia. The rats were randomly divided into four groups of twenty animals each. The experimental groups $(n=5)$ were G1 (Saline); G2 (crude methanol plant extract 2\% + Carbopol Gel 98\%); G3 (crude methanol plant extract 2\% + lanolin/vaseline) and G4 (laser). The incision healing processes were monitored during 3, 7, 14 and until 21 days after excision. The histologic parameters evaluated were Collagen fiber types, microscopic examination and neovascularization. There was a significant increase in the deposition of collagen fibers, as evidenced by a better organized epithelial tissue, keratinized and showing greater proliferation of new blood vessels in the inflammatory phase in the group treated with both the extract and laser. The results were correlated to the phenolic derivatives found after qualitative and quantitative analysis. These compounds were considered responsible for the healing process. The topical treatment with $S$. hispida leaves, in the two different formulations, was more effective than the application of the laser (Ingan ALP) $660 \mathrm{~nm}$ in the model used.
\end{abstract}

Keywords: laser therapy, tissue repair, inflammatory cells, medicinal plants.

\section{Potencial cicatrizante da pomada de Sebastiania hispida (Mart.) Pax (Euphorbiaceae) comparado ao laser de baixa potência}

\begin{abstract}
Resumo
A cicatrização deficiente representa uma complicação grave em algumas patologias e o uso de extratos de plantas tem demonstrado melhora no processo de reparação tecidual. O objetivo deste estudo foi avaliar o potencial cicatrizante da pomada de Sebastiania hispida comparado ao Laser Indio Phosphide-Gallium-Aluminum (InGaAlP) em feridas cutâneas induzidas cirurgicamente em ratos e realizar analise fitoquímica. A análise fitoquímica foi via clássica e por CLAE. O experimento foi desenvolvido com 80 ratos (200-250 g), divididos aleatoriamente em quatro grupos $(\mathrm{n}=5)$ : G1 (salina); G2 (extrato bruto metanólico 2\% + Carbopol Gel 98\%); G3 (extrato bruto metanólico 2\% + lanolina/ vaselina) e G4 (laser). Após a tricotomia da região dorsal realizou uma excisão linear, medindo $2 \mathrm{~cm} \times 1 \mathrm{~cm}$ (epiderme e derme), expondo a fáscia muscular. Em sequência os tratamentos e o monitoramento do processo de cicatrização das feridas cirúrgicas ocorreu nos tempos de: 3, 7, 14 e até 21 dias após a excisão. Os parâmetros histológicos avaliados
\end{abstract}


foram: tipos de fibras colágenas, avaliação morfológica e neovascularização. Houve uma deposição significativa de fibras colágenas, evidenciado por um tecido epitelial mais bem organizado, queratinizado e mostrando uma maior proliferação de novos vasos sanguíneos na fase inflamatória do grupo tratado com o extrato e o laser. A eficiência do processo de cicatrização pode estar relacionada com a presença de compostos fenólicos e derivados detectados na análise qualitativa e quantitativa. A utilização do tratamento tópico com as duas formulações diferentes de $S$. hispida foram mais eficazes do que a aplicação do Laser (InGaAlP) no modelo utilizado.

Palavras-chave: terapia a laser, reparação de tecidos, células inflamatórias, plantas medicinais.

\section{Introduction}

The skin is the first barrier protecting the body against the aggression of external agents, which can trigger the loss of tissue integrity. The discontinuity in tissue integrity can be induced either by trauma or by surgical procedures. Therefore, maintaining skin's integrity and function is very important for human survival (Kottner et al., 2013). Aggressors come in distinct nature, such as mechanical, physical, chemical or infectious ways. In the presence of tissue injury, numerous mechanisms start to affect the injured area (Velnar et al., 2009). Tissue repairing is a systemic and dynamic process and it starts a cascade of physiological phenomena causing tissue changes as the inflammatory, the proliferative and remodeling processes (Delavary et al., 2011).

The healing process is the result of several cellular, molecular and biochemical phenomena. These phenomena are characterized by chemotaxis, neovascularization, proliferation and deposition of extracellular matrix reorganization culminating in the tissue repair (Kottner et al., 2013). The use of herbal systems, particularly the topical ones, has been increased in recent years with the research of substances that have effective role to improve tissue repair (Lopes et al., 2005).

Sebastiania hispida (Mart.) Pax (Euphorbiaceae) is among the plants used in the healing process, it is an herb or subshrub species, found in semi-flooded fields, sandy soils and deforested areas in Mato Grosso do Sul State, Brazil. This species is notable for presenting steroids, triterpenoids, flavonoids, tannins and saponins, which are chemical compounds that have pharmacological properties (Hnatyszyn et al., 2007). Moreover, several studies have shown that the use of low-power laser has beneficial therapeutic results on the cicatrization in different tissues (Lopes et al., 2009; Moraes et al., 2012). The main medical applications of LLLT are in reducing pain and inflammation, augmenting tissue repair and promoting regeneration of different tissues and nerves, and in preventing tissue damage in situations where it is likely to occur (Byrnes et al., 2004). The objective of this study was to evaluate the healing activity of $S$. hispida ointment in different carriers comparing it with the effects of aluminium-gallium indium-phosphide laser (InGaAlP) in second-intention wound in rats' model.

\section{Material and Methods}

\subsection{Collection of botanical material and preparation of extracts}

The leaves of S. hispida (Mart.) Pax (Euphorbiaceae) were collected on 19/10/2010, in Campo Grande, Mato Grosso do Sul, Brazil (20²6'10'S; 5451'44”O). A voucher specimen was deposited at the Herbarium of AnhangueraUniderp University under number 7826, identified by the Botanist Eloty J. Dias Schleder (Anhanguera - Uniderp University). To collect and research purposes was obtained authorization for access to genetic resources of The Genetic Patrimony Board of Management (CGEN) under the registration number 010579 / 2013-3.

The plant material was dried in an oven at $45{ }^{\circ} \mathrm{C}$ (Marconi $\left.^{\circledR}, \mathrm{MA} 35\right)$ for $72 \mathrm{~h}$, grounded with an industrial blender (Skymsen ${ }^{\circledR}$, LS-04), producing $500 \mathrm{~g}$ of powder, which was submitted to extraction with methanol in ultrasonic bath (Unidque $\left.{ }^{\circledR}, 1450\right)$ for 60 minutes. The extract was extracted by maceration until exhaustion with solvent change after $24 \mathrm{~h}$. Then, the filtrates were concentrated under reduced pressure in a rotating evaporator (Tecnal, MA120) producing the dry crude methanolic extract that was used for the preparation of the ointment, phytochemical analysis, and biological experiments.

\subsection{Topical formula preparation}

After obtaining the crude plant methanolic extract (leaves), it was incorporated into two types of carriers, which was based on Carbopol Gel and lanolin/vaseline (1:1). The concentration established was $2 \%$ crude extract and $98.0 \%$ the carriers.

\subsection{Phytochemical analysis}

Previous phytochemical investigation of the methanolic extracts was performed regarding phenolic compounds, tannins, coumarins, naphthoquinone, glycosides anthraquinone, steroids, triterpenes, cardiotonic glycosides, cyanogenic glycosides, saponin and reducing sugars, following Matos (2009) procedure. Flavonoids and the total phenolic compounds were determined based on he Folin-Ciocalteu method (Turkmen et al., 2006).

Equipment, instrumental and chromatographic conditions: The leaf methanolic extract was diluted with methanol to a final concentration of $10 \mathrm{mg} \mathrm{mL}^{-1}$ and then submitted to High Performance Liquid Chromatography (HPLC) analysis in a Shimadzu SCL-10AVP equipped with degasser DGU-14A, binary pump LC-10AD, oven 
CTO-10AS, auto-injector SIL-10AF and diode array detector SPD-M10A. The analyses were performed on a reverse-phase LiChrospher-100 RP-18 Merck column $(250 \mathrm{~mm} \times 4.6 \mathrm{~mm}$ i.d.; $5 \mu \mathrm{m}$ particle size; Darmstadt, Germany) equipped with a Merck guard column $(10 \mathrm{~mm} \times 4.0 \mathrm{~mm}$ i.d.) packed on the same packing material and placed before the inlet of the analytical column. A gradient of ultrapure water acidified with glacial acetic acid $(\mathrm{pH}=3.0)(\mathrm{A})$ and acetonitrile (B) was used as follows: 0 minutes $=95 \%(\mathrm{~A}) / 5 \%(\mathrm{~B})$; 80 minutes $=5 \%(\mathrm{~A}) / 95 \%(\mathrm{~B})$; and then $95 \%(\mathrm{~A}) / 5 \%$ (B) with 10 minutes of equilibrating time. Flow rate was set at $1.0 \mathrm{~mL} / \mathrm{min}$, oven temperature was set at $50{ }^{\circ} \mathrm{C}$ and detection was performed at $220 \mathrm{~nm}$ and $340 \mathrm{~nm}$. The mobile phase was previously filtered through a $0.45 \mathrm{~mm}$ filter (Millipore, Bedford, MA) and degassed in ultrasonic bath for 15 minutes. Chromatograms were visualized and manipulated in Class-VP software.

\subsection{Animals}

All experiments were carried out on 80 adult male Wistar rats (200-250 g) maintained at the University Anhanguera-Uniderp Animal Care Facility. The rats were taken to the testing room at least $1 \mathrm{~h}$ before experiments and were studied for 21 days. All animals were allowed free access to food and water throughout the study. Animal care and handling procedures were in accordance with the International Association for Study of Pain guidelines on the use of animals in pain research and they were approved (number 2757-1) by Animal Ethnical Comity of Unicamp University.

\subsection{Experimental model}

The rats were anesthetized with sodium pentobarbital $\left(10 \mathrm{mg} \mathrm{kg}^{-1}\right)$ administered by intraperitoneal rout (i.p.) and submitted to the following surgical procedure: antiseptic solution (2.0\% iodine alcohol) applied topically on the surgical site before each operation to prevent skin's infection and desiccation. The dorsal region was shaved and an excision was performed using $\mathrm{n}^{\circ} 15$ surgical blades. The skin excision thickness was $2 \mathrm{~cm} \times 1 \mathrm{~cm}$, (epidermis and dermis), and exposed the muscle fascia. Subsequently, the rats were separated into four groups of twenty animals each randomly assigned to control and test groups. The experimental groups were: G1 (Saline); G2 (plant's crude methanolic extract 2.0\% + Carbopol Gel 98\%); G3 (plant's crude methanolic extract 2.0\%+ lanolin/vaseline) and G4 (laser).

These treatments were initiated immediately after surgery, control group received 10 drops of saline on the entire excision; the experimental groups were treated with $1.0 \mathrm{~g}$ of ointment once a day at the same time daily during 21 days. Photograph pictures were taken from animal groups in three days intervals to evaluate the cicatrization evolution. Five animals of each group were euthanized with sodium pentobarbital ( $50.0 \mathrm{mg} \mathrm{kg}^{-1}$; i.p.) in 3, 7, 14 and 21 days after surgical procedures.

\subsection{Histological analysis}

After animal euthanasia, the dorsal area was surgically removed, fixed in buffered $4.0 \%$ paraformaldehyde. Then, the samples were embedded in paraffin blocks and sectioned in $5 \mu \mathrm{m}$-thick samples with a microtome (Microm HM320). The resulting sections were stained with hematoxylin and eosin (Luna, 1968), Gomori's Trichrome and Picrosirius Red (Borges et al., 2007). The stained samples were examined under optical microscopy (Carl Zeiss).

\subsection{Aluminium-Gallium-Indium-Phosphide Laser (InGaAlP)) $660 \mathrm{~nm}$ therapy procedure}

Each animal in the treated group G4 received transcutaneous InGaAlP laser irradiation (DMC ${ }^{\circledR}$ brand Photon Laser III model), application during 3, 7, 14 and 21 days after surgical procedures, every day. Laser array was positioned at a $90^{\circ}$ angle over the injured area, at $660 \mathrm{~nm}$ for 40 seconds per point (five points, four in the edges and one in the center), potency of $100 \mathrm{~mW}, 0.028 \mathrm{~cm}^{2}$ spot area and energy density of 4 joules $/ \mathrm{cm}^{2}$.

\subsection{Immunohistochemistry reaction}

It was performed according to the immunoperoxidase technique. The monoclonal antibodies used were FlK-1 and VEGF (C-17) (1:100). Primary antibody incubation was performed during the overnight period and kept at $4{ }^{\circ} \mathrm{C}$. After this period, they were washed with Phosphate-Buffered Saline (PBS). The secondary antibody Goat Anti-Rabbit $\operatorname{IgG}(\mathrm{H}+\mathrm{L})$, biotinylated and streptavidin, and Peroxidase (rabbit ImmunoCruz Staining System: sc-2051.) were incubated with the material for 30 minutes at $4{ }^{\circ} \mathrm{C}$. In order to visualize the reaction, the sections were treated with Diaminobenzidine chromogen solution (Kit DAB-DAKO ${ }^{\circledR}$ ) (DAB + CHOROMOGEN - 5.0 mL; DAB + SUBSTRATE BUFFER - $110 \mathrm{~mL}$ ) and counter-staining was performed with Harris' Hematoxylin for 30 seconds. Afterwards, the dehydration was carried out with $100 \%$ ethanol baths and clarified with xylene at room temperature. For the setting of the slides Entellan was used (MERCK 7961).

\subsection{Number of capillaries}

The capillaries at the injury site that immunolabeled for VEGF receptor-1 (Flt-1/VEGFR-1) were considered neoformed capillaries. Capillaries were counted in 125 spots per treatment $(n=5 \mathrm{rat} /$ group and 25 spots/animal at each of the six time-points of G1, G2, G3 and G4 experimental groups). In all groups, the counting of blood vessels was made in a "Hot Spot" region comprising the tissue field with higher density of vessels within the damaged area. An Axiolab light microscope (Zeiss, objective $40 \times$ ) coupled to a video camera Sanyo Digital Active BLC and connected to a video plaque equipped Pentium III $700 \mathrm{MHz}$ was used for capturing images.

\subsection{Drugs and reagents}

The carbopol gel and lanolin/vaseline were obtained from a local drugstore (Drogaderma drugstore). The monoclonal antibodies FIK-1 and VEGF (C-17) (1:100), secondary antibody Goat Anti-Rabbit $\operatorname{IgG}(\mathrm{H}+\mathrm{L})$, Diaminobenzidine 
chromogen solution, streptavidin and peroxidase (rabbit ImmunoCruz Staining System: sc-2051.) were obtained from Santa Cruz Biotechnology, California, USA.

\subsection{Statistical analysis}

Results are presented as means \pm S.E.M. and are representative of two separate experiments of five animals per experimental time/group. Two-way analysis of variance (ANOVA) was used to compare the groups and times. The analyzed factors were treatments, time and time versus treatment interaction. When there was a significant time versus treatment interaction, one-way ANOVA followed by Bonferroni's test was performed for each time. The pictures were measured in AutoCAD program (Autodesk Inc. 2012). Statistical differences were considered to be significant at $\mathrm{P}<0.05$.

\section{Results}

\subsection{Phytochemical analysis}

The phytochemical screening of S. hispida leaf extract and stems indicated the presence of phenolic compounds (Strongly positive $=+++$ ), tannins (Strongly positive $=+++$ ), flavonoids moderately positive $=++$ ), steroids and free triterpenes (weakly positive $=+$ ). The analysis with the dry drug indicated the presence of saponins and cardiac glycosides.

The HPLC analysis of the leaf methanolic extract showed signals between 10 and 25 minutes, indicating that this extract is rich in medium-polar compounds (Figure 1A, B). The main compounds were registered at 14.9 (6.3\%), 15.5 (13.4\%), 16.3 (18.8\%), 17.3 (5.8\%), 18.8 (11.9\%), $19.3(5.8 \%), 20.4$ (8.6\%), $21.5(3.3 \%)$, comprising 54.2\% of the mixture. The UV spectra of the signals at 14.9, 15.5, $16.3,17.3,18.8$ and 19.3 minutes showed $\lambda_{\text {max }}$ in $220 \mathrm{~nm}$ and $270 \mathrm{~nm}$, suggesting the presence of organic phenolic compounds (Figure 1C). UV spectra of the signals at 20.4 and 21.5 minutes showed $\lambda_{\max }$ in $246 \mathrm{~nm}$ and $350 \mathrm{~nm}$, indicating the presence of the benzopirone skeleton, characteristics of flavonoids (Figure 1D) (Marston, 2007; Zeraik and Yariwake, 2010).

The total phenolic contents and total flavonoids for the methanolic extract of $S$. hispida were determined and

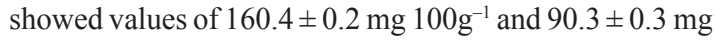
of quercetin $100 \mathrm{~g}^{-1}$ respectively.

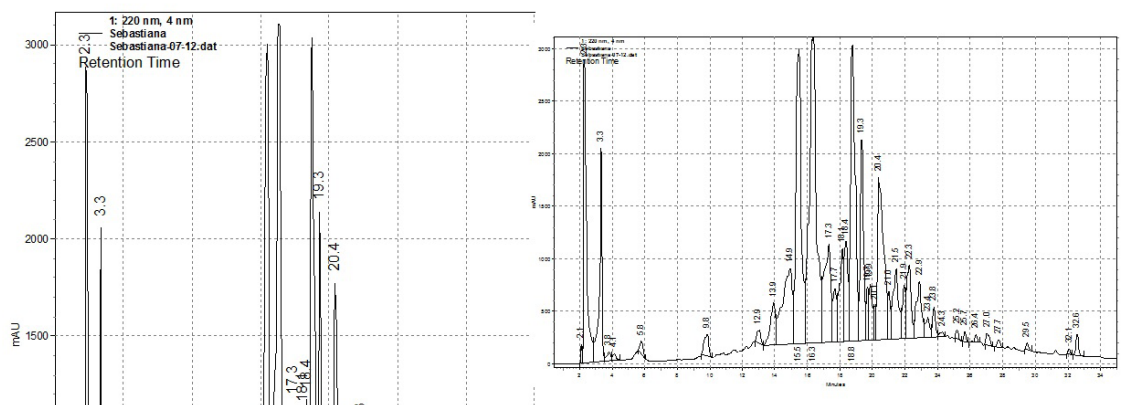

Figure 1B: Expansion.

Figure 1A: HPLC profile from the leaves

methanolic extract of the $S$. hispida
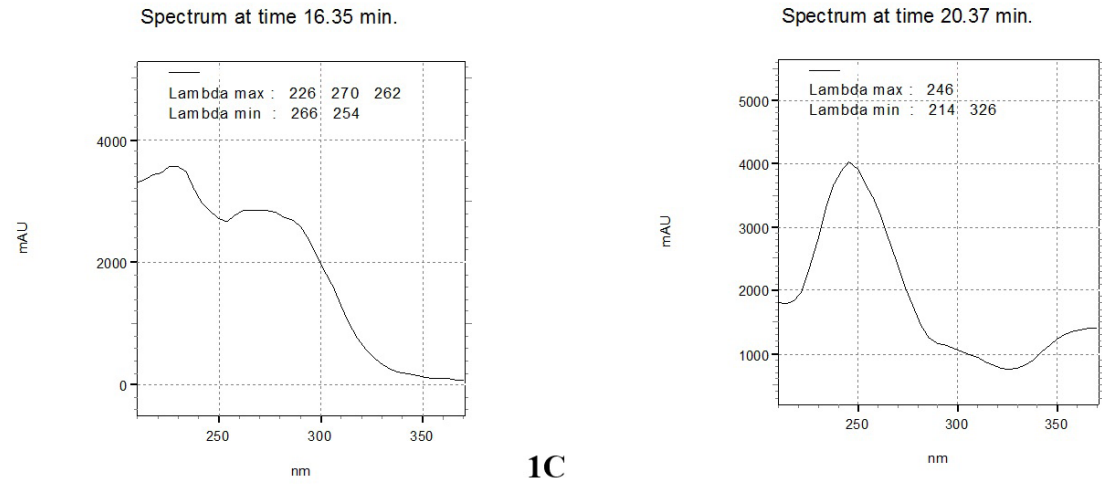

$1 D$

Figure 1. HPLC: UV-DAD spectra (200-400 nm) using HPLC (A) method; (B) rt = 16.28 min.; (C) $\mathrm{rt}=20.44 \mathrm{~min}$. chromatogram and UV spectra of the main compounds from the methanolic extract of the $S$. hipida leaves $(\mathrm{C}$ and $\mathrm{D})$. 


\subsection{Macroscopic examination}

The methanol extract (leaves) of S. hispida has shown phenolic compounds and derivatives such as tannins, demonstrating astringent properties, which allowed the precipitation of cells, and the formation of a protective coating against bacteria for the injured tissues; therefore, promoting an antiseptic action on the injured site.

\subsection{Microscopic examination}

Light microscopic examinations of samples were taken from all groups during all the analyzed periods. The results showed complete regression within 14 days after the excision groups G2, G3 and G4, as compared to the group G1. On the 21st day after the excision, in groups G2, G3 and G4 it was observed a smooth and normal epithelial organization with the presence of keratin. In the dermis, it was observed the proliferation of fibroblasts with active and fusiform nucleus, presence of collagen fibers and vessels although it was not observed the presence of associated structures such as hair and sebaceous follicles, and sweat glands. After the analysis of all groups at all different periods, it was observed that the G3 and G4 showed better results compared with microscopic morphological G1 and G2. The epithelium was shown to be organized and it was present in all animals. The inflammation was absent or restricted to small areas. The dermis showed organization of the collagen fibers (Figure 2).

\subsection{Collagen fibers quantification}

The collagen fiber deposition was observed on $3^{\text {rd }}, 7^{\text {th }}$ and $14^{\text {th }}$ days after incision and was higher on $21^{\text {st }}$ in the G2, G3 and G4 groups when compared with G1 group (Figure 3).

The enhanced deposition of collagen fibers In the $21^{\text {st }}$ day results suggested that the therapeutic use of $S$. hispida methanolic crude extract in G2 (70\%) G3 and G4 was more successful for improving collagen deposition when compared with G1 group.

\subsection{Collagen fibers type I and III}

The collagen fibers of G1 group under polarized light (Picrosirius Red) showed delicate fibers with yellow-green color birefringence, featuring a type III collagen from $3^{\text {rd }}$,

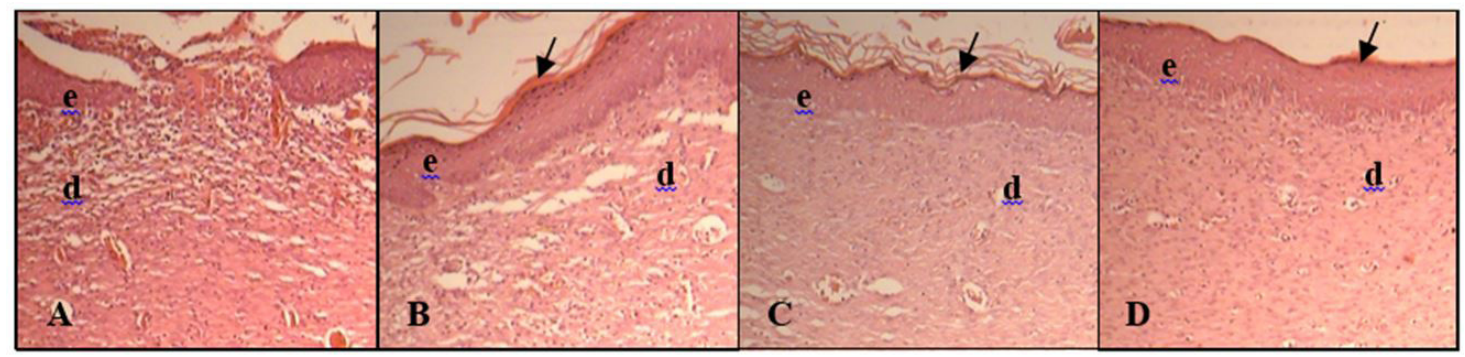

Figure 2. 14 days, (A) G1; (B) G2; (C) G3; (D) G4. Epidermis (e); dermis (d); queratin (arrows). HE. 200×.
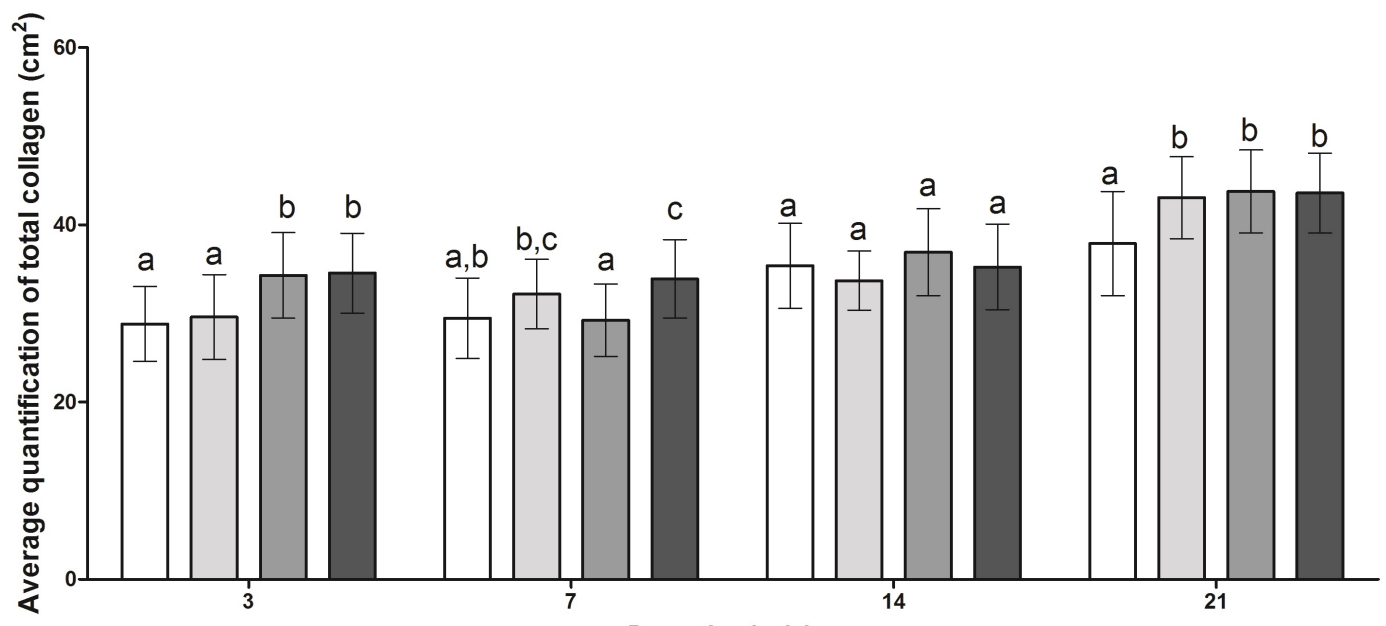

Days after incision

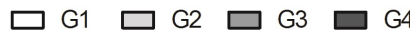

Figure 3. Quantification of total collagen. At 21 days the G2, G3 and G4 groups showed the largest areas $(\mathrm{P}<0.05)$ of collagen respectively, compared with the areas of G1. The results of the statistical tests are shown by letters. The same letters at each bar are not significantly different. One-way ANOVA followed by Bonferroni $\mathrm{T}$ test $(\mathrm{P}<0.05)$. 
to $21^{\text {st }}$ days after excision. Its amount was larger $(\mathrm{P}<0.05)$, when compared with the other groups during $3^{\text {rd }}$ and $14^{\text {th }}$ days. At $21^{\text {st }}$ day only G2 group maintained it's amount of Type III fibers despite the others. It was observed that the morphological characterization of collagen fibers in the G2, G3 and G4 groups had a predominance of type I collagen since the $3^{\text {rd }}$ when compared, in the same time, with $\mathrm{G} 1$ group. This observation reveals that $\mathrm{S}$. hispida and Laser improve the healing of injured area since the beginning of lesion (Figure 4).

\subsection{Neovascularization}

Neovascularization was observed intensely on the $3^{\text {rd }}$ and $7^{\text {th }}$ day after excision in the G2 and G3 groups (Figure 5). Furthermore, on the $7^{\text {th }}$ day after excision only G2 group demonstrated increase $(\mathrm{P}<0.05)$ in the proliferation of new blood vessels. The slide analysis of the $14^{\text {th }}$ and $21^{\text {st }}$ day after incision demonstrated no statistical differences $(\mathrm{P}>0.05)$ among the control and treatment groups regarding the proliferation of new blood vessels. These results indicate that the topical treatment with S. hispida incorporated in carbopol gel or lanolin/vaseline carrier exhibited more proliferation of new blood vessels in inflammatory phase when compared with laser application.

\section{Discussion}

The occurrence of phenolic compounds (gallicina, gallic acid, syringic acid, caffeic acid) and flavonoids (quercetin, kaempferol, campesterol; isorhamnetin; isoquercitrin) was reported for the species $S$. brasiliensis, S. argutidens and S. Commersoniana (Penna et al., 2001; Hnatyszyn et al., 2007). From the aerial parts of $S$. macrocarpa a mixture of steroids $\beta$-sitosterol and stigmasterol, gallic acid and scopoletin was isolated (Lima et al., 2009a). There were no studies reporting the content of total phenolic compounds and flavonoids in the S. hispida.
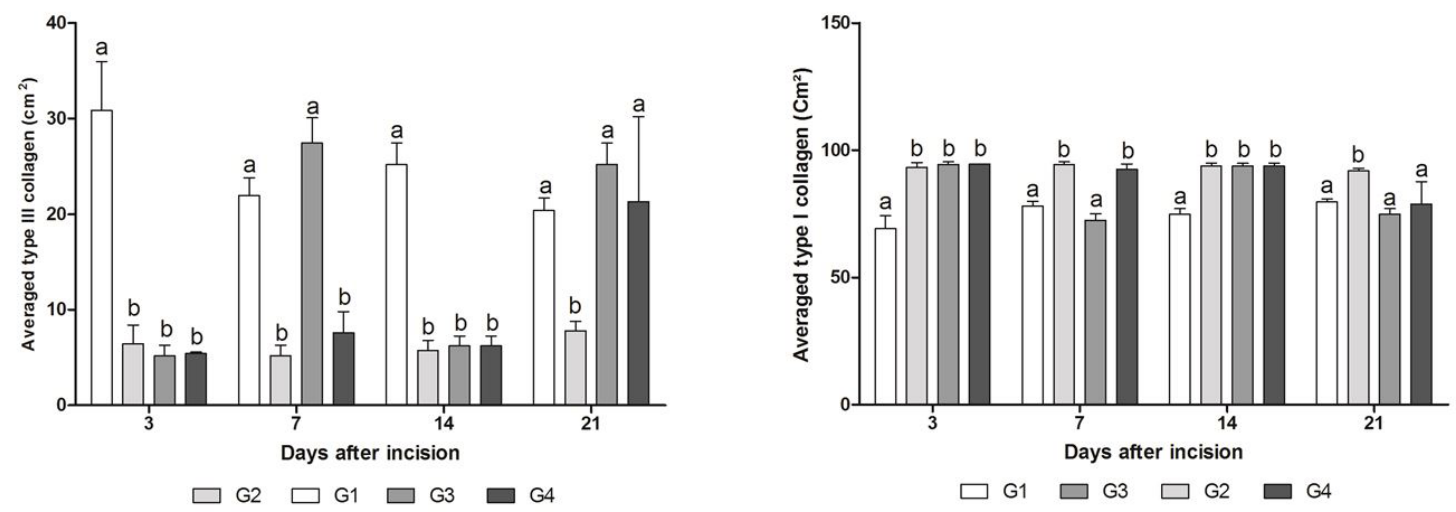

Figure 4. Quantification of collagen (left) type III and (right) type I. It's observed that the amount of type I collagen is increased since the early lesions. The results of the statistical tests are shown by letters. The same letters at each bar are not significantly different. One-way ANOVA followed by Bonferroni T test $(\mathrm{P}<0.05)$.

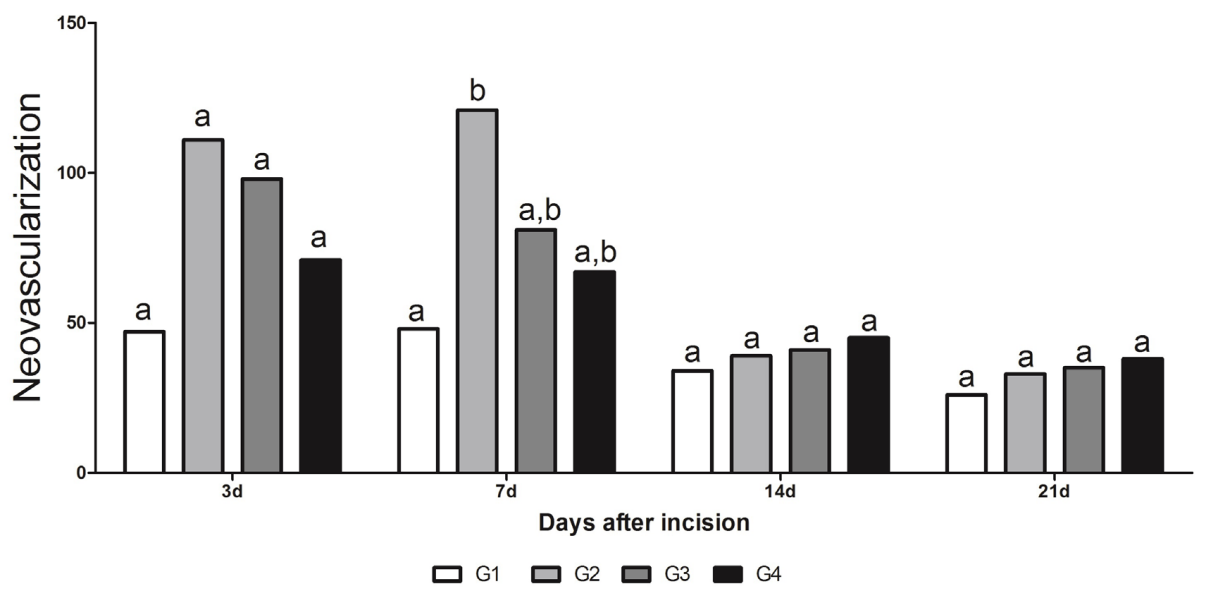

Figure 5. Neovascularization observed in a rat model: control and experimental groups. The results of the statistical tests are shown by letters. The same letters at each bar are not significantly different. Two-way ANOVA followed by Bonferroni $\mathrm{T}$ test $(\mathrm{P}<0.05)$. 
The clot formation and the presence of fibrin and inflammatory exudate are important for the occurrence of coaptation of the wounds' edges, the intersection of fibronectin, providing a provisional matrix (fibrin crust), so that the fibroblasts, endothelial cells and keratinocytes can enter the wound (Mandelbaum et al., 2003; Servin et al., 2006). Clinically, the healing process is characterized by four biologically distinct phases; the inflammatory, the proliferative and the remodeling phase. Histological changes and wound healing characterize each of these phases. Synthetic or natural medications play an active role in different phases of wound healing (Kottner et al., 2013).

The effectiveness of $S$. hispida can be justified due important to secondary metabolites, such as flavonoids and tannins, which have already demonstrated their antiinflammatory and antioxidant properties (Bahramsoltani et al., 2014; Scur et al., 2016). Published data demonstrate that pharmacological activity of $S$. hispida species reduces the inflammatory process induced by crude venom injection of Bothrops moojeni (Dourado et al., 2012). Furthermore, it is popularly employed in treating external wounds (Pott and Pott, 1994).

In fact, in the treatment groups, results have demonstrated full incision regression within 14 days after incision and the epithelium organization was regular and normal in all these groups. The inflammatory process was restricted in minor areas. Moreover, in these groups an enhanced deposition of collagen fibers was observed, and evidenced better organized and keratinized epithelial tissue. These results are interesting because of biological events such as progressive deposition and remodeling of collagen fibers in association with controlled inflammatory processes that are important and crucial to a complete and effective tissue healing (Lima et al., 2009b; Velnar et al., 2009). The fibroplasia is extremely important in the formation of granulation tissue. With an increase of activated fibroblasts to produce collagen, the extracellular matrix begins to be replaced by a connective stronger and more elastic tissue (Balbino et al., 2005; Gumel et al., 2015). Thus, these results suggest the beneficial therapeutic effect of crude methanolic extract of $S$. hispida as with the laser in the healing process. Type I collagen is the most abundant type of collagen observed in normal dermis (approximately $80 \%$ to $90 \%$ ). However, during the early phases of wound healing, fibroblasts actively produce type III collagen, which may account for $30 \%$ of the total collagen in a healing wound. By week 2, type I collagen again becomes the principal collagen produced by fibroblasts. Type I and type III collagen are formed in skin in a higher proportion in relation to other types and are maintained in a fixed relative proportion to one another in normal skin tissue (Cheng et al., 2011; Sarandy et al., 2015).

In the present study, the results have revealed that the topical treatment with $S$. hispidain gel carbopol or lanolin/vaseline demonstrated the same expression of type I collagen fibers when compared with laser application. According to (Viegas et al., 2001) the combination of vaseline and lanolin anhydrous solid results in a hydrophobic, oily and aqueous excipient mixture, promoting at the same time an occlusive effect (vaseline) and endodermal activity (lanolin) in order to penetrate the skin, improving the absorption of the active principles in deeper tissue layers, but without reaching the bloodstream.

The main proliferative processes that occur during the wound healing are angiogenesis, fibroplasias leading to collagen production and epithelialization. Fibroblasts secrete growth factors and extracellular matrix components while endothelial cells contribute to the formation of new vasculature leading to tissue regeneration (Keyhani et al., 2001; Hicklin and Ellis, 2005).

The angiogenesis phenomenon is essential to carry oxygen to ischemic or newly formed healing tissues. Stimulating the growth factors and other mediators, endothelial cells of intact vessels inside the margins of the wound migrate toward the injured area; then they differentiate to form new capillaries in the outer side of vessels. Further, these capillaries join the original capillaries and restore blood flow (Balbino et al., 2005). In this experiment, the number of newly formed vessels in the G2 group demonstrated increase in the proliferation of new blood vessels, aiding the production of collagen by fibroblasts and epithelialization with a superior period on treated lesions.

In the present study the macroscopic examination on the $21^{\text {st }}$ day of healing revealed that all the treatments protocols were effective in the regression of the incision, the lesion area was less than $1 \mathrm{~cm}$. Although the macroscopic results did not demonstrate statistical differences among the groups, histological differences occurred particularly in the structural organization of collagen fibers and the angiogenesis increase.

The low-level laser application focusing tissue repair and regeneration is a common practice in the treatment of skin disorders. Several studies can be found in the literature regarding the laser's clinical efficacy in healing process (Melo et al., 2011). The therapeutic effects of laser irradiation in healing process are dependent on the anti-inflammatory activity, epithelium cells proliferation stimulation, fibroblast proliferation and collagen fibers synthesis increase (Posten et al., 2005), moreover, the collagen fiber production is more organized (Medrado et al., 2008). Therefore, the laser clinical efficacy in healing process is attributed not only to their proliferative activities, but also to their anti-inflammatory effects (Albertini et al., 2007). The same results are observed with topical pharmaceutical formulations with wound healing properties.

Although several studies on laser photobiomodulation ensured the improvement of scar repair, specially secondintention wound healing, some studies compared the clinical efficacy of laser application with topical herbal medicine (Catarino et al., 2015; Jácomo et al., 2015).

In this study, it was found that the use of two formulas (carbopol gel and lanoline/vaseline), based on the methanolic extract from the leaves of $S$. hispida, was more efficient in the regression of wounds than the use of low intensity laser. The efficiency of the two formulas was observed with the formation of organic epithelium at 14 days and 
in the dermis, the proliferation of fibroblasts and blood vessels with the consequent formation of collagen fibers, occurred. These discoveries can be mainly attributed to the phenolic compounds and derivatives. The phenolic compounds and derivatives (flavonoids and tannins) can simultaneously inhibit the oxidation of the arachidonic acid stopping the synthesis of prostaglandin E2 and thus reducing the swelling (Shin et al., 2004). It also suggests that the triterpenes and saponins, found in the methanolic extract, also have a part in this capacity. Properties are attributed to these two phytochemicals, chiefly anti-inflammatory and vascular system protection and specifically to the triterpenes that inhibit the action of COX-1 and COX-2 (Nangia-Makker et al., 2007) and thus contribute with the inflammatory response.

\section{Conclusion}

The results suggest that topical treatment with S. hispida in two formulations is more efficient than aluminiumgallium-indium-phosphide laser (InGan AlP) 660nm.

Both the topical treatment with S. hispida, carbopol gel and lanolin/vaseline, were effective in increasing collagen type I synthesis and the process of angiogenesis in the inflammatory phase in rats models. This activity is related to the presence of phenolic compounds and derivatives.

The results indicate that the pharmaceutical forms used were efficient in wound healing, with the potential of producing a phytomedicine of topical use of S. hispida leaf extract-based ointment.

\section{Acknowledgements}

The authors are grateful for financial support from the Conselho Nacional de Desenvolvimento Científico e Tecnológico $(\mathrm{CNPq})$ for the present PQ2 research grants; the Coordenação de Aperfeiçoamento de Pessoal de Nível Superior (CAPES); the Instituto Nacional de Áreas Úmidas (INAU); the Centro de Pesquisa do Pantanal (CPP), CNPq, Fundação de Apoio ao Desenvolvimento do Ensino, Ciência e Tecnologia de Mato Grosso do Sul (FUNDECT), Fundação Nacional de Desenvolvimento do Ensino Superior Particular (FUNADESP) and the Anhanguera-Uniderp University.

\section{References}

ALBERTINI, R., VILLAVERDE, A.B., AIMBIRE, F., SALGADO, M.A., BJORDAL, J.M., MUNIN, E. and COSTA, M.S., 2007. Anti-inflammatory effects of low-level laser therapy (LLLT) with two different red wavelengths $(660 \mathrm{~nm}$ and $684 \mathrm{~nm})$ in carrageenan-induced rat paw edema. Journal of Photochemistry and Photobiology B: Biology, vol. 89, no. 1, pp. 50-55. http:// dx.doi.org/10.1016/J.Jphotobiol.2007.08.005.

BAHRAMSOLTANI, R., FARZAEI, M.H. and RAHIMI, R., 2014. Medicinal plants and their natural components as future drugs for the treatment of burn wounds: an integrative review. Archives of Dermatological Research, vol. 306, no. 7, pp. 601-617. http://dx.doi.org/10.1007/s00403-014-1474-6. PMid:24895176.
BALBINO, C.A., PEREIRA, L.M. and CURI, R., 2005. Mecanismos envolvidos na cicatrização: uma revisão. Revista Brasileira de Ciências Farmacêuticas = Brazilian Journal of Pharmaceutical Sciences, vol. 41, no. 1, pp. 27-51.

BORGES, L.F., GUTIERREZ, O.S., MARANA, H.R.C. and TABOGA, S.R., 2007. Picrosirius-polarization staining method as an efficient histopathological tool for collagenolysis detection in vesical prolapse lesions. Micron (Oxford, England), vol. 38, no. 6, pp. 580-583. http://dx.doi.org/10.1016/j.micron.2006.10.005. PMid:17126553.

BYRNES, K.R., BARNA, L., CHENAULT, V.M., ILEY, I.K., LONGO, L., MIRACCO, C., JOHNSON, B. and ANDERS, J.J., 2004. Photobiomodulation improves cutaneous wound healing in an animal model of type II Diabetes. Photomedicine and Laser Surgery, vol. 22, no. 4, pp. 281-290. http://dx.doi.org/10.1089/ pho.2004.22.281. PMid:15345169.

CATARINO, H.R.C., GODOY, N.P., SCHARLACK, N.K., NEVES, L.M.G., GASPIS, F.O.G., ESQUISATTO, M.A.M., AMARAL, M.E.C., MENDONÇA, F.A.S. and SANTOS, G.M.T., 2015. InGaP $670 \mathrm{~nm}$ laser therapy combined with a hydroalcoholic extract of Solidago chilensis Meyen in burn injuries. Lasers in Medical Science, vol. 30, no. 3, pp. 1069-1079. http://dx.doi. org/10.1007/s10103-014-1707-0. PMid:25600614.

CHENG, W., YAN-HUA, R., FANG-GANG, N. and GUO-AN, Z., 2011. The content and ratio of type I and III collagen in skin differ with age and injury. African Journal of Biotechnology, vol. 10, no. 13, pp. 2524-2529. http://dx.doi.org/10.5897/AJB.10.1999.

DELAVARY, B.M., VAN-DER-VEER, W.M., VAN-EGMOND, M., NIESSEN, F.B. and BEELEN, R.H., 2011. Macrophages in skin injury and repair. Immunobiology, vol. 216, no. 7, pp. 753762. http://dx.doi.org/10.1016/J.imbio.2011.01.001.

DOURADO, D.M., SILVA, A.A., SILVA, B.A.K., TOZETTI, I.A., FERMIANO, M.H., GUILHERMINO, J. and MATIAS, R., 2012. Efeito da planta Sebastiana hispida no fígado de ratos injetados com veneno de Bothrops moojeni, correlacionados com marcadores enzimáticos e laser de baixa potencia. Revista Fitos Eletrônica, vol. 7, no. 3, pp. 137-145.

GUMEL, A.M., RAZAIF-MAZINAH, M.R., ANIS, S.N. and ANNUAR, M.S., 2015. Poly (3-hydroxyalkanoates)-co-(6hydroxyhexanoate) hydrogel promotes angiogenesis and collagen deposition during cutaneous wound healing in rats. Biomedical Materials (Bristol, England), vol. 10, no. 4, pp. 1-11. http:// dx.doi.org/10.1088/1748-6041/10/4/045001. PMid:26154416.

HICKLIN, D.J. and ELLIS, L.M., 2005. Role of the vascular endothelial growth factor pathway in tumor growth and angiogenesis. Journal of Clinical Oncology, vol. 23, no. 5, pp. 1011-1027. http://dx.doi.org/10.1200/JCO.2005.06.081. PMid:15585754.

HNATYSZYN, O., JUAREZ, S., OUVINA, A., MARTINO, V., ZACCHINO, S. and FERRARO, G., 2007. Phytochemical analysis and antifungal evaluation of Sebastiania commersoniana extracts. Pharmaceutical Biology, vol. 45, no. 5, pp. 404-406. http://dx.doi.org/10.1080/13880200701215216.

JÁCOMO, A.C.J., VELOZO, K.A., LOTTI, R.G., NEVES, L.M.G., GASPI, F.O.G., ESQUISATTO, M.A.M., AMARAL, M.E.C., MENDONÇA, F.A.S. and SANTOS, G.M.T., 2015. Activity of Porophyllum ruderale leaf extract and 670-nm InGaP laser during burns repair in rats. BMC Complementary and Alternative Medicine, vol. 15, no. 274, pp. 1-9. http://dx.doi.org/10.1186/ S12906-015-0805. PMid:26269145. 
KEYHANI, A., JENDIROBA, D.B. and FREIREICH, E.J., 2001. Angiogenesis and leukemia. Leukemia Research, vol. 25, no. 8, pp. 639-645. http://dx.doi.org/10.1016/S0145-2126(00)00161-2. PMid:11397467

KOTTNER, J., LICHTERFELD, A. and BLUME-PEYTAVI, U., 2013. Maintaining skin integrity in the aged: a systematic review. British Journal of Dermatology, vol. 169, no. 3, pp. 528-542. http://dx.doi.org/10.1111/bjd.12469. PMid:23773110.

LIMA, C.C., PEREIRA, A.P.C., SILVA, J.R.F., OLIVEIRA, L.S., RESCK, M.C.C., GRECHI, C.O., BERNARDES, M.T.C.P., OLÍMPIO, F.M.P., SANTOS, A.M.M., INCERPI, E.K. and GARCIA, J.A.D., 2009b. Ascorbic acid for the healing of skin wounds in rats. Brazilian Journal of Biology $=$ Revista Brasileira de Biologia, vol. 69, no. 4, pp. 1195-1201. http://dx.doi.org/10.1590/ S1519-69842009000500026. PMid:19967193.

LIMA, M.A.A., LIMA, J.Q., ARRIAGA, Â.M.C., ANDRADENETO, M., SANTIAGO, G.M.P., BEZERRA, B.P., FEREIRA, Y.S., VERAS, H.N.H. and BRAZ-FILHO, R., 2009a. Constituintes químicos de Sebastiania macrocarpa Muell. Arg. (Euphorbiaceae). Quimica Nova, vol. 32, no. 2, pp. 348-353a. http://dx.doi. org/10.1590/S0100-40422009000200015.

LOPES, G.C., SANCHES, A.C., NAKAMURA, C.V., DIAS FILHO, B.P., HERNANDES, L. and MELLO, J.C., 2005. Influence of extracts of Stryphnodendron polyphyllum Mart. and Stryphnodendron obovatum Benth. on the cicatrisation of cutaneous wounds in rats. Journal of Ethnopharmacology, vol. 99, no. 2/3, pp. 265-272. http://dx.doi.org/10.1016/j.jep.2005.02.019. PMid: 15894137

LOPES, K.A.R., VELHO, N.M.R.C. and MUNIN, E., 2009. A study of low power laser on the regenerative process of Girardia tigrina (Girard,1850) (Turbellaria; Tricladida; Dugesiidae). Brazilian Journal of Biology $=$ Revista Brasileira de Biologia, vol. 69, no. 2, pp. 327-332. http://dx.doi.org/10.1590/S151969842009000200013. PMid:19675934.

LUNA, L.G., 1968. Manual of histologic staining methods of the Armed Forces Institute of Pathology. 3rd ed. New York: McGraw-Hill.

MANDELBAUM, S.H., DI SANTIS, E.P. and MANDELBAUM, M.H.S.A., 2003. Cicatrização: conceitos atuais e recursos auxiliares. Parte I: educação médica continuada. Anais Brasileiros de Dermatologia, vol. 78, no. 4, pp. 393-410. http://dx.doi. org/10.1590/S0365-05962003000400002.

MARSTON, A., 2007. Role of advances in chromatographic techniques in phytochemistry. Phytochemistry, v. 68, no. 22/24, pp. 2785-2797. http://dx.doi.org/10.1016/J.Phytochem.2007.08.004.

MATOS, J.F.A., 2009. Introdução a fitoquímica experimental. Fortaleza: UFC. 141pp.

MEDRADO, A.P., SOARES, A.P., SANTOS, E.T., REIS, S.R. and ANDRADE, Z.A., 2008. Influence of laser photobiomodulation upon connective tissue remodeling during wound healing. Journal of Photochemistry and Photobiology. B, Biology, vol. 92, no. 3, pp. 144-152. http://dx.doi.org/10.1016/j.jphotobiol.2008.05.008. PMid: 18602833 .

MELO, V.A., ANJOS, D.C.S., ALBUQUERQUE JUNIOR, R., MELO, D.B. and CARVALHO, F.U.R., 2011. Effect of low level laser on sutured wound healing in rats. Acta Cirurgica Brasileira, vol. 26, no. 2, pp. 129-134. http://dx.doi.org/10.1590/S010286502011000200010 . PMid:21445476.
MORAES, J.M., MENDONÇA, D.E.O., MOURA, V.B.L., OLIVEIRA, M.A.P., AFONSO, C.L., VINAUD, M.C., BACHION, M.M. and LINO JUNIOR, R.S., 2012. Anti-inflammatory effect of low-intensity laser on the healing of third-degree burn wounds in rats. Lasers in Medical Science, vol. 28, no. 4, pp. 1169-1176. http://dx.doi.org/10.1007/s10103-012-1213-1. PMid:23053250.

NANGIA-MAKKER, P., TAIT, L., SHEKHAR, M.P.V., PALOMINO, E., HOGAN, V., PIECHOCKI, M.P., FUNASAKA, T. and RAZ, A., 2007. A inibição do crescimento do tumor da mama e de angiogénese por uma erva medicina: Ocimum gratissimum. International Journal of Cancer, vol. 121, no. 4, pp. 884-894. http://dx.doi.org/10.1002/ijc.22733. PMid:17437270.

PENNA, C., MARINO, S., VIVOT, E., CRUANES, M.C., MUNOZ, J.D., CRUANES, J., FERRARO, G., GUTKIND, G. and MARTINO, V., 2001. Antimicrobial activity of Argentine plants used in the treatment of infectious diseases: isolation of active compounds from Sebastiania brasiliensis. Journal of Ethnopharmacology, vol. 77, no. 1, pp. 37-40. http://dx.doi. org/10.1016/S0378-8741(01)00266-5. PMid:11483376.

POSTEN, W., WRONE, D.A., DOVER, J.S., ARNDT, K.A., SILAPUNT, S. and ALAM, M., 2005. Low-level laser therapy for Wound Healing: mechanism and efficacy. Dermatologic Surgery, vol. 31, no. 3, pp. 334-340. http://dx.doi.org/10.1097/00042728200503000-00016. PMid:15841638.

POTT, A. and POTT, V.J., 1994. Plantas do Pantanal. 1. ed. Corumbá: Empresa Brasileira de Pesquisa Agropecuária.

SARANDY, M.M., NOVAES, R.D., MATTA, S.L., MEZENCIO, J.M., SILVA, M.B., ZANUNCIO, J.C. and GONÇALVES, R.V., 2015. Ointment of Brassica oleracea var. capitata matures the extracellular matrix in skin wounds of wistar rats. Evidence-Based Complementary and Alternative Medicine, vol. 1, pp. 1-9. http:// dx.doi.org/10.1155/2015/919342. PMid:26170889.

SCUR, M.C., PINTO, F.G.S., PANDINI, J.A., COSTA, W.F., LEITE, C.W. and TEMPONI, L.G., 2016. Antimicrobial and antioxidant activity of essential oil and different plant extracts of Psidium cattleianum Sabine. Brazilian Journal of Biology = Revista Brasileira de Biologia, vol. 76, no. 1, pp. 101-108. http:// dx.doi.org/10.1590/1519-6984.13714. PMid:26871744.

SERVIN, S.C.N., TORRES, O.J.M., MATIAS, J.E.F., AGULHAM, M.A., CARVALHO, F.A., LEMOS, R., SOARES, E.W.S., SOLTOSKI, P.R. and FREITAS, A.C.T., 2006. Ação do extrato de Jatropha gossypiifolia L. (pião roxo) na cicatrização de anastomose colônica: estudo experimental em ratos. Acta Cirurgica Brasileira, vol. 21, suppl. 3, pp. 89-96. http://dx.doi.org/10.1590/ S0102-86502006000900012. PMid:17293941.

SHIN, K.M., KIM, I.T., PARK, Y.M., HA, J., CHOI, J.W., PARK, H.J., LEE, Y.S. and LEE, K.T., 2004. Anti-inflammatory effect of caffeic acid methyl ester and its mode of action through the inhibition of prostaglandin $\mathrm{E}_{2}$, nitric oxide and tumor necrosis factor- $\alpha$ production. Biochemical Pharmacology, vol. 68, no. 12, pp. 2327-2336. http://dx.doi.org/10.1016/j.bcp.2004.08.002. PMid:15548379.

TURKMEN, N., SARI, F. and VELIOGLU, Y.S., 2006. Effects of extraction solvents on concentration and antioxidant activity of black and black mate tea polyphenols determined by ferrous tartrate and Folin-Ciocalteu methods. Food Chemistry, vol. 99 , no. 4 , pp. 835-841. http://dx.doi.org/10.1016/j. foodchem.2005.08.034.

VELNAR, T., BAILEY, T. and SMRKOLJ, V., 2009. The wound healing process: an overview of the cellular and molecular mechanisms. 
The Journal of International Medical Research, vol. 37, no. 5, pp. 1528-1542. http://dx.doi.org/10.1177/147323000903700531. PMid:19930861.

VIEGAS, T.X., VAN WINKLE, L.L., LEHMAN, P.A., FRANZ, S.F. and FRANZ, T.J., 2001. Evaluation of creams and ointments as suitable formulations for peldesine. International Journal of Pharmaceutics, vol. 219, no. 1-2, pp. 73-80. http://dx.doi. org/10.1016/S0378-5173(01)00632-9. PMid:11337167.

ZERAIK, M.L. and YARIWAKE, J.H., 2010. Quantification of isoorientin and total flavonoids in Passiflora edulis fruit pulp by HPLC-UV/DAD. Microchemical Journal, vol. 96, no. 1, pp. 8691. http://dx.doi.org/10.1016/j.microc.2010.02.003. 